Grygorii Deinychenko, Doctor of Engineering Sciences, Professor ORCID: 0000-0003-3615-8339 ResearcherID: https://publons. com/researcher/3442989/grygorii-deinychenko/

Inna Zolotukhina, $\mathrm{PhD}$ in Engineering Sciences, Doctoral ORCID: 0000-0003-1900-2682, ResearcherID: http://www. researcherid. com/rid/M-2778-2018 Kharkiv State University of Food Technology and Trade, Kharkiv, Ukraine

Tatiana Yudina, Doctor of Engineering Sciences, Professor ORCID: 0000-0001-9863-878X ResearcherID: https://publons. com/researcher/N-4770-2016/ Kyiv National University of Trade and Economics Kyiv, Ukraine

\title{
INFLUENCE OF TECHNOLOGICAL PARAMETERS OF LOW-CALCIUM BUTTERMILK COPRECIPITATE ON ITS RHEOLOGICAL CHARACTERISTICS
}

The necessity of development of obtaining technologies of low-calcium buttermilk co-precipitates with a complex of necessary technological properties is proved in the article. The influence of the buttermilk pasteurization parameters on the degree of transition of solids, protein and fat to the coagulate process was determined.

Keywords: buttermilk, protein, pasteurization, low-calcium co-precipitate, supreme shear stress.

Relevance of the research topic: The traditional technology of industrial dairy processing does not allow using all components of milk in dairy products such as butter, sour cheese, cheese and others. While their production one inevitably will receive protein-carbohydrate dairy raw materials (PCDRM) in the form of skim milk, buttermilk and whey. 
One of the PCDRM types formed during the milk processing is the buttermilk obtained during the production of butter [4]. In the total volume of PCDRM produced, the buttermilk is characterized by a relatively low specific gravity, which, in our opinion, explains the insufficient attention to the development of issues for their further use in human nutrition.

Of great interest in these raw materials are protein substances that determine the biological value of buttermilk [2]. However, existing technologies of buttermilk processing are far from fully exploiting their nutritional potential, in particular, the protein complex.

Formulation of the problem: The development of methods and regimes of the buttermilk proteins co-precipitation process, technologies of obtaining of low-calcium co-precipitates from this raw material with a complex of necessary technological properties for the subsequent use in technologies of restaurant industry foods is an important task.

Analysis of recent researches and publications: The research of chemical composition, nutritional value of dairy raw materials and the development of technologies of protein foods were of interest of many domestic and foreign scientists: V. Belitser, P. F. Dyachenko, M. M. Lipatov (senior), A. G. Khramtsov. In Ukraine, these issues were researched by S. S. Gulyaev-Zaitsev, G. V. Deinychenko, V. M. Kozlov, G. E. Polishchuk, G. B. Rudavska, N. A. Tkachenko, T. I, Yudina etc [1, 4-5].

The quality of the food depends largely on the cooking technology. Since products of different quality can be obtained from the same raw material, it is necessary to study the influence of technological factors on the consistency of the finished product.

Presenting main material: In the first stage of the study, the influence of the parameters of the buttermilk pasteurization on the degree of transition of solids, protein and fat to the coagulate process was determined.

In order to establish the optimum temperature interval for the buttermilk heating, as well as to study the effect of different temperatures on the physic-chemical and organoleptic parameters of the obtained coagulate - low calcium co-precipitate the buttermilk were heated to temperatures in the range of $80 \ldots 95^{\circ} \mathrm{C}$ for $10 \mathrm{~min}$. Pre-prepared acidic serum was added in small portions with a thin stream, the mixture was gently stirred. Serum was taken in the amount of $30 \%$ of the buttermilk volume. The mixture was allowed to rest for $10 \mathrm{~min}$, and the released coagulate was filtered through lavsan tissue and left for self-pressing for 1,0 to 1,5 hours. As an objective indicator of the low-calcium co-precipitate consistency the supreme shear stress (SSS) was used.

The results of the obtained protein masses studies are presented in Fig. 1.

The analysis of the obtained data shows that the temperature of buttermilk pasteurization significantly affects the main characteristics of the resulting protein mass. Thus, with pasteurization temperature increase from 80 to $95{ }^{\circ} \mathrm{C}$, the degree of released solids increases by $10,2 \%$, of protein - by $10,1 \%$, of fat - by $7,7 \%$. The increase in the degree of $\mathrm{S}, \mathrm{P}$ and $\mathrm{F}$ transition is also evidenced by the decrease in their mass particles in the formed serum. 
As the temperature of buttermilk pasteurization increases, the moisture content of the protein mass decreases. Increasing the pasteurization temperature has a negative effect on the clot's water-binding capacity. In our view, this is due to the fact that the influence of high temperatures (above $90{ }^{\circ} \mathrm{C}$ ) leads to the denaturation of serum proteins and their aggregation with casein [3]. The influence of lactic acid on the protein globules (after mixing the buttermilk and whey) accelerates the syneresis of the gel, which is accompanied by intense moisture squeezing from polymers of milkprotein mass. Moreover, the higher the temperature, the syneresis process is more intense, so the consistency becomes denser.
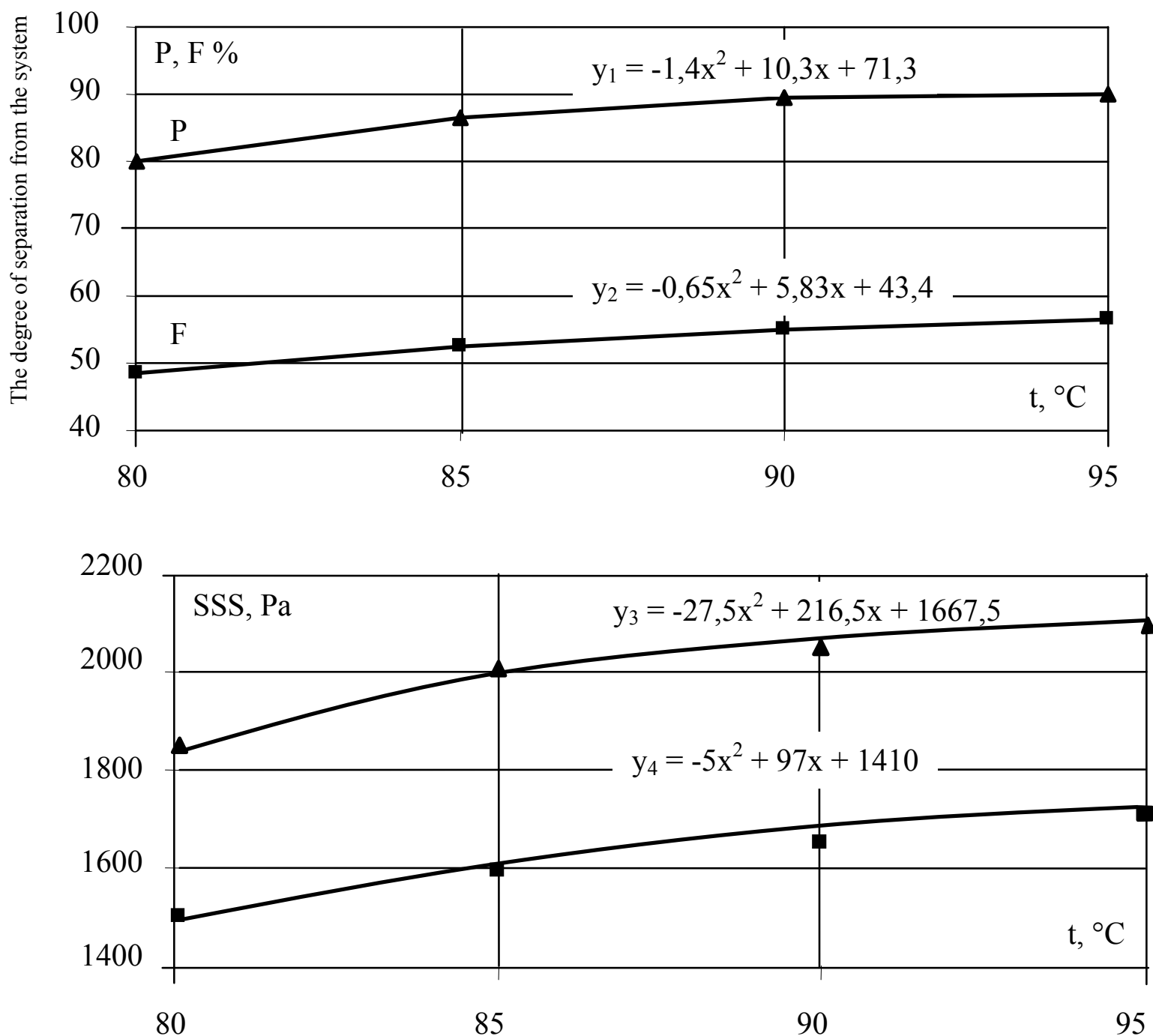

SSS: befortubbing

$\rightarrow-$ after rubbing

Figure 1. The influence of pasteurization temperature on the precipitation process and the characteristics of the coagulate 
According to the above, the consistency of the obtained low-calcium coprecipitate changes from paste-like to granular. The SSS of the product rises with pasteurization temperature increase from $1850 \mathrm{~Pa}$ to $2100 \mathrm{~Pa}$. Wiping of the lowcalcium co-precipitate improves its consistency, reducing SSS by $18 \ldots 19 \%$.

It should also be noted that the analyzed temperature range has no significant effect on the active acidity of the protein masses and on some organoleptic indicators (taste, smell).

The influence of the duration of buttermilk pasteurization at $95{ }^{\circ} \mathrm{C}$ on the main characteristics of the obtained protein masses is presented in Fig. 2.
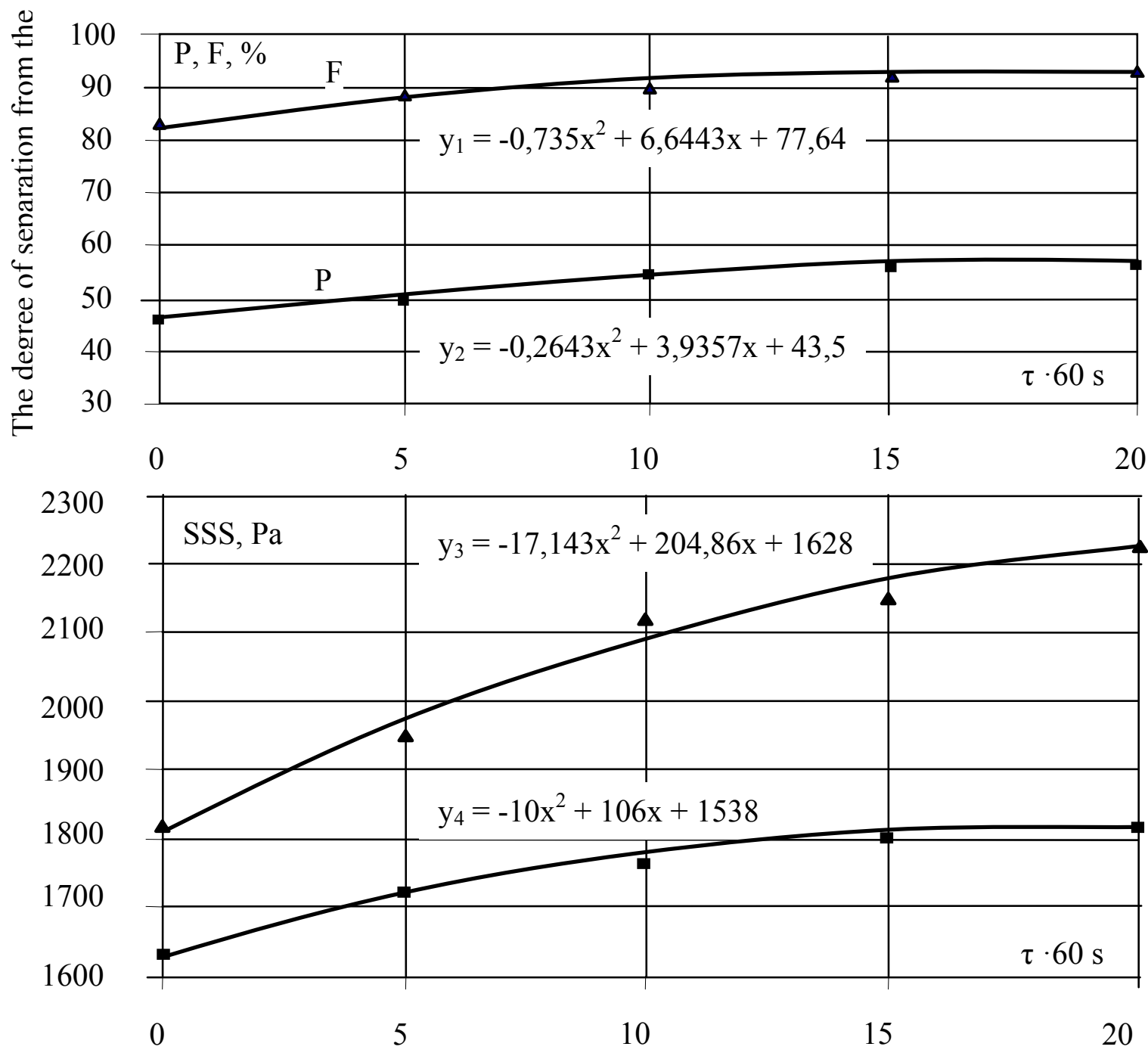

SSS: beforerubbing

$\rightarrow$ after rubbing

Figure 2. The influence of the duration of buttermilk pasteurization on the precipitation process and the characteristics of the coagulate 
According to the obtained data, with increasing the pasteurization duration the degree of solids and protein separation from model systems increases. The most intensive increase in the degree of released solids and protein is observed in the range $(10 \ldots 15) \cdot 60 \mathrm{~s}$, after which the rate of increase in the degree of released solids and macromolecular compounds is significantly reduced. Thus, with increasing the duration of buttermilk pasteurization from 0 to $10.60 \mathrm{~s}$, the degree of released solids increased by $7,4 \%$, of proteins - by $7,1 \%$, of fat - by $8,5 \%$, and the subsequent pasteurization of buttermilk for $10 \cdot 60 \mathrm{~s}$ (from 10 to $20 \cdot 60 \mathrm{~s}$ ) leads to an increase in the rate of released solids by $3,5 \%$, of proteins - by $2,8 \%$, of fat - by $1,8 \%$.

The decrease in humidity of co-precipitate, as already noted, is apparently a consequence of the intense syneresis process due to the increase in the duration of high-temperature effects on the buttermilk proteins during their precipitation with acidic serum.

With the duration of buttermilk pasteurization more than (10..15).60 s, sensory indicators of the resulting protein quality, such as taste and smell, are significantly disimproved. The sugary taste and odor of pasteurization are formed as a result of the intense melanoidin reaction, since the temperature of $93 . .95^{\circ} \mathrm{C}$ is the limit for its onset, which significantly disimproves the quality of the obtained coagulate.

Conclusions: Therefore, the most optimal modes of buttermilk pasteurization, which contribute to the maximum release of solids and proteins and do not disimprove the qualitative indicators of low-calcium co-precipitate, are pasteurization temperature $93 \ldots 95^{\circ} \mathrm{C}$ and duration $(10 \ldots 15) \cdot 60 \mathrm{~s}$.

\section{REFERENCES}

1. Gnitsevich, V. Yudina, T., Deynichenko L. (2016) Tekhnolohiya ta biolohichna tsinnist molochno-bilkovykh kopretsypitativ [Technology and biological value of milk-protein coprecipitates] Goods and markets. - № 2. - P. 148-157. Retrieved from: http://nbuv. gov. ua/UJRN/tovary_2016_2_19. [in Ukrainian].

2. Gunkova, P. Y. (2015) Byotexnologycheskye svojstva belkov moloka [Biotechnological properties of milk proteins]: monografyya rekomendovana dlya nauchnix y ynzhenerno-texnycheskyx rabotnykov pyshhevoj promishlennosty, a takzhe prepodavatelej, aspyrantov y studentov vuzov - SPb. : GYORD - 216 p. [in Russian].

3. Development in dairy chemistry / Edited by P. P. Fox. - Applied Science Publishers Ltd. - Riple Road, Backing, Essex England. - 1982. P. 21.

4. Deynichenko, G., Maznyak Z, Zolotukhina, I. (2008) Ultrafiltratsiyni protsesy ta tekhnolohiyi ratsionalnoyi pererobky bilkovo-vuhlevodnoyi molochnoyi syrovyny [Ultrafiltration processes and technologies of rational processing of proteincarbohydrate milk raw materials]. - Kh. : Fact, - 208p. [in Ukrainian].

5. Yudina, T. I. (2016) Naukove obhruntuvannya tekhnolohiy strukturovanoyi kulinarnoyi produktsiyi $\mathrm{z}$ vykorystannyam kontsentrativ skolotyn [Scientific substantiation of the technologies of the structured culinary production with the use of concentrates of buttermilk] (Doktoral dissertation). - Kyiv. - 406 p. [in Ukrainian]. 